\title{
A GYÓGYPEDAGÓGIAI SZEMLÉLET INTEGRÁLÓDÁSA A BUDAI TANÍTÓKÉPZÉSBE
}

\section{Rózsáné Czigány Enikő}

Eötvös Loránd Tudományegyetem

Több mint fél évszázados vita a pedagógiában, hogy meg kell-e szüntetni vagy fenn kell-e tartani a szegregációt, az együtt- vagy a különnevelés szolgálja-e jobban a speciális szükségletü tanulók személyiségfejlődését, társadalmi integrációját? A csak a problémára, fogyatékos gyermekek esetében a tünetekre koncentráló szelekció, azaz a szegregált nevelés vagy a teljes személyiséget, az egészséges szocializációt, a gyermeki jogokat alapul vevő integrált nevelés érvényesüljön-e? A tanító- és gyógypedagógus-képzést is érintő szemléletek harca a kutatás és képzés szintjén megoldódni látszik, habár az integrált nevelés tartalmának változása folyamatos, rövid időn belüli gyors alkalmazkodást, új stúdiumok kidolgozását és/vagy a már oktatott tárgyak tartalmának változtatását, kibővítését igényli.

A politikai rendszerváltás környékén a szakértői bizottságok által integrálhatónak ítélt fogyatékos gyermekek egy meglévő struktúrába való fogadására helyezték a hangsúlyt, melyben külön rehabilitációs foglalkozások keretében biztosították a speciális fejlesztést. Majd az 1994-es salamancai nyilatkozatot követően már a „valamennyi gyermeket a többségi iskolába” szemlélet fogalmazódott meg, ami az inklúzió alapja. Természetesen a nyilatkozat is deklarálja, hogy lehetnek olyan gyermekek, akik számára csak a szegregáció a járható út. Az inklúzió, azaz a befogadás maximálisan figyelembe veszi az egyéni szükségleteket, s azokból kiindulva, azokra építve biztosítja a nevelési lehetőségeket. Míg a fogadás a gyermektől várja az alkalmazkodást, addig az inkluzív befogadó pedagógia a gyermekhez alkalmazkodik. Ez viszont a gyakorló pedagógusoktól is szemléletváltást, új ismeretek, módszerek alkalmazását várta el, ami a tanítóképzésre is új feladatokat rótt. A fenti folyamatok értelmében a többségi pedagógus- és gyógypedagógus-képzés tartalmi munkáját és a gyógypedagógiai szemlélet tanítóképzésben való megjelenését tekintve három fázist különböztethetünk meg.

\section{Az egyéni sajátosságokat figyelmen kívül hagyó, teljesítményorientált, szegregált oktatási forma}

A XIX. és XX. században a természet- és a társadalomtudományok forradalmi elöretörésével változott az emberideál, az intellektuális teljesítmények felértékelődtek. Általánossá vált, hogy különbséget tettek jó és gyengébb képességü tanulók között. Ahhoz, hogy eredményes iskoláztatásuk megvalósulhasson, a pedagógusképzésnek is alkalmazkodnia kellett. Ekkor fogalmazódott meg erőteljesen az igény, hogy a fogyatékos gyermekek számára is létesítsenek iskolákat, intézeteket. 
Európában, így hazánkban is a XIX. század elejétől a XX. század első negyedéig felgyorsult a különböző fogyatékosságoknak megfelelő iskolatípusok alapítása, s ezzel együtt az iskolarendszer képességek szerinti differenciálódása. 1890-ig a gyógypedagógiai ismereteket Bécsben, illetve az 1880-as években néhány éven keresztül kísérleti jelleggel a tanítóképezdékben sajátíthatták el azok a jelöltek, akik speciális intézményekben kívántak tanítani. A budai, a pozsonyi és még néhány képezde jó szándékú erőfeszítései azonban a tanítóképzés zsúfolt tantervi programjai miatt rövid időn belül meghiúsultak (Gordosné, 2010).

Hazánkban gyógypedagógusi képzést 1890 és 1900 között tanfolyami jelleggel a fogyatékosságtípusnak megfelelő intézmények szerveztek. Kizárólag az általuk gondozott sérüléstípus gyógypedagógiai nevelésére készítettek fel. Ezek résztvevői csak tanítók, okleveles tanárok, tanárjelöltek, illetve olyan teológusok és lelkészek lehettek, akik igazoltan pedagógiai végzettséggel is rendelkeztek. Például 1894-től a Roboz József által alapított ortophonikus intézetben a hibásbeszédủekkel való foglalkozásra, tanításukra logopédiai tanfolyamokon sajátíthatták el a pedagógusok a speciális ismereteket (Gordosné, 2000a). 1900ban, a gyógypedagógiai intézmények számának gyarapodásával párhuzamosan, Vácott létrehozták az egyesített Gyógypedagógiai Tanítóképzőt, amely 1904-től már Budapesten müködött.

A gyógypedagógus-képzés egészen 1963-ig minden fogyatékossági típus oktatására, nevelésére, fejlesztésére, gondozására egységes felkészítést adott. Először (1900-tól 1922-ig) kétéves, majd 1922-től már a Gyógypedagógiai Tanárképző keretében hároméves, és 1928-tól a föiskolai szintü négyéves képzés során. Ekkor már nemcsak a pedagógiai végzettséggel rendelkezők nyerhettek felvételt, hanem a pedagógiai elöképzettség nélküli érettségizettek is, azzal a feltétellel, hogy a négyéves gyógypedagógus-képzést követően plusz egy év alatt kell a tanítói végzettséget megszerezniük. Ez a követelmény 1953-ig volt érvényben.

A Magyar Állami Gyógypedagógiai Tanárképző Főiskola 1946. évi szervezeti, tanulmányi és fegyelmi szabályzata a sok szakmai vitát, diszfunkciót kiváltó egységes gyógypedagógus-képzést érintően is változást hozott (Gordosné, 2000a). Az eltérő feladatokra való felkészítés sajátos szakosodást engedélyez, az egységes 6 féléves képzést követően a 7. félévben egy fö és két mellékszakot választhattak a hallgatók. 1963-tól a szakosodás három, 1968-tól két, s azt követően 1999-től egyszakos formában valósult meg, de 2012 szeptemberétől ismét a kétszakos képzés lép életbe.

Mint láthattuk, a gyógypedagógus-képzésben a tanítóképzés vagy előfeltételként, vagy kötelező kiegészítésként volt jelen. Ennek oka, az, hogy a gyógypedagógus-képzésben föleg az orvosi szemlélet uralkodott. Ez tette szükségessé olyan elméleti és módszertani ismeretek elsajátítását, amelyeket a gyógypedagógiai ismeretekkel ötvözve a sérült gyermekek eredményes tanításában alkalmazni tudtak. Ugyanakkor felvetődik a kérdés, hogy a gyógypedagógia - az 1880-as évek rövid életű próbálkozásaitól eltekintve - mikor 
és milyen igények megfogalmazását követően jelent meg, vesz részt és milyen tartammal a tanítóképzésben?

1945-től a 6 osztályos népiskolák helyébe a 8 osztályos általános iskolák lépnek. 1946-ban megjelenik az első általános iskolai tanterv. Egy évvel később az általános iskolai meghatározást alapul véve már megjelenik a gyógypedagógiai iskolák egységes tanterve is, de csak az 1949-es VKM 5300/1949. sz. rendelet mondja ki a gyógypedagógiai intézmények általános iskolai jellegét. Ez a szemlélet azonban nem hosszú életü, mert a különböző politikai ideológiák a gyógypedagógiát sem kímélik. „Az 1961. évi oktatási törvény az első átfogó oktatási törvény a II. világháború után, amely azért is rendkívül fontos és jelentős, mert végre a tanköteles korú fogyatékos gyermekek iskolázási jogát már az alaptörvényben kinyilvánítja. A 4. § így szól: »A testileg, érzékszervileg vagy értelmileg fogyatékos, de képezhetö tanköteles gyermekek oktatása és nevelése gyógypedagógiai intézményekben történik. «" (Gordosné, 2000b. 17.) Ezzel azonban a többségi pedagógia és a gyógypedagógia, valamint a tanító- és gyógypedagógus-képzés hosszú időre elkülönült egymástól.

A speciális óvodák, iskolák szervezésének gyógypedagógiai felfogásában is föleg az orvosi szemlélet uralkodott, mert a sérülésre összpontosítva határozták meg a „sokoldalú” személyiségfejlődést biztosító kezelés színhelyét. Ezek a sérüléstípusra specializálódott intézmények gyakran egy-egy település szélén, a többségi gyermekintézményektől és sokszor a családtól is távol helyezkedtek el. Ezért a más településeken élök nagy részét bentlakással kiemelték természetes családi és lakókörnyezetükből. A komplex fejlesztő folyamatoknak voltak bizonyítható értékei, de káros következményekkel is jártak, mivel megbontották a szocializációs folyamatok és a pszichés fejlődés egyensúlyát. Ez a szemlélet mind a gyógypedagógiában, mind a többségi pedagógiában azt a gyakorlatot eredményezte, hogy az egyéni különbségeket figyelmen kívül hagyva, homogén csoportként kezelték a gyermekeket. Annak ellenére, hogy megtapasztalták az eltéréseket, nem kellett ezeket figyelembe venni. Többségükben nem, vagy csak elvétve alkalmazták az egyéni bánásmód, a differenciálás módszereit. Ez a szemlélet jellemezte a pedagógusképzést és a gyakorlatot is.

\section{A többségi iskolákba történő fogadást lehetővé tevő integrációs nevelésre való felkészítés}

Az USA-ban és a skandináv országokban már az 1960-as évek elején egymást követték az integrációs törekvések, majd a speciális igényeket figyelembe vevő törvények, rendeletek, melyek lehetővé tették a különböző okok miatt akadályozott gyermekek együttnevelését ép társaikkal, egyéni oktatási program megvalósításával (Csányi, 1995; Réthy, 2002; Torgyik, 2004). A polgárjogi, oktatáspolitikai kezdeményezések mellett szemléletváltozás jött létre a tanulási és magatartászavarok értelmezésében, azok korrekciójában is. Neuropszichológiailag is alátámasztották, hogy a tanulási zavar csak akkor kezelhető eredményesen, ha a fejlesztésnél nem elkülönítetten a tünetre koncentrálnak, hanem azokra az idegrendszeri struktúrákra is, amelyekröl beigazolódott, hogy az ép müködés 
alapját adják (Bálint, 1987). Az idejében elkezdett korrekció a gyermekek egy részénél teljes javulást is eredményezhet, amelynek eredményeként megelőzhetőek a tanulási zavarra ráépülö magatartászavarok, és tanulási motivációjukat sem vesztik el a gyermekek.

Magyarországon a 70-es évek közepétöl, a politikai enyhülést követően a nyugat-európai tanulmányutak során szerzett tapasztalatok és a szakirodalom révén, főleg a pedagógiai mühelyek kutatóiban és a Bárczi Gusztáv Gyógypedagógiai Tanárképző Főiskola oktatóiban fogalmazódott meg a társadalmi és az óvodai, iskolai nevelést érintő integrációs igény. 1981-ben a gyógypedagógia megújítását célzó kutatások közt már a fogyatékos tanulók integrált nevelése is előtérbe került. Ennek eredményeként kísérleti jelleggel a kutatásban részt vevő Fejér megye iskoláiban a spontán integrálódott gyermekek fejlesztésére, szüleik és pedagógusaik segítésére utazó gyógypedagógusi ellátást szerveztek. A különböző kutatómühelyek részeredménye volt az általános iskolai korrekciós osztályok létrehozása. Igaz, ez még nem a fogyatékos gyermekeket érintő integrációs nevelés, de azon speciális szükségletü tanulók társadalmi integrációját szolgálhatta, akik tanulás- és/vagy magatartászavarral küzdöttek, és felzárkóztatásuk eredményes volt.

A szakszerü korrekciós szemléletet magáénak vallva időben reagált a Budapesti Tanítóképző Főiskola, már az 1980-ban bevezetett új tanítóképzős főiskolai tanterv óra- és- vizsgatervében heti két órában szerepelt a korrekciós nevelés tantárgy. Nem találtam olyan forrást, amely a tematikát tartalmazta vagy arra utalt volna, ezért csak az 1981-től a tárgyat oktató Gereben Ferencné visszaemlékezésére hagyatkozhatom. Tehát a korrekciós nevelés tematikája tartalmazta a tanulási zavarok, a nehezen nevelhetőség kóroktanát, tünettanát, valamint nagyobb hangsúlyt fektetett az olvasás-, írás-, helyesírás- és magatartászavarok korrekciójára egyéni, kiscsoportos és osztálykeretek között. Ekkor a hallgatók még főleg logopédiai és pszichopedagógiai ismereteket, szemléletet sajátíthattak el. Az 1983-as, „A tanítóképző főiskolai tanterv megvalósításának tapasztalatai és a tantervi korrekcióra irányuló javaslatok" címú kiadvány arról is tanúskodik, hogy a korrekciós szemlélet nemcsak a pedagógiában, hanem a pedagógiai pszichológiában is megjelent. Ugyanezen kiadványban szerepel, hogy szükségesnek tartanák a korrekciós foglalkozások gyakorlati képzésbe való beépítését is.

Az 1985. évi I. törvény végrehajtásaként 1987-ben jóváhagyott tanítóképzős tantervi irányelvek elkészítésében a Budapesti Tanítóképző Főiskolán oktató több kollégájával együtt részt vett Hunyadi Györgyné. Az irányelvek a pedagógiai tárgyakhoz kapcsolódóan, a tanítói műveltség, szemlélet alakításában szükségesnek tartják a tájékozottság szintjén a „speciális (gyógypedagógiai) ismeretek oktatását, valamint a differenciálás gyakorlatára való felkészítést”. Ezt erősíti a gyakorlati képzés is, amelynek egyik követelménye a kisiskolások tanulási folyamatainak differenciált irányítása, tervezése (Hunyadyné és mtsai. 1987). Ekkor azonban már életbe lépett az oktatásról szóló 1985. évi I. törvény, amely elörevetítette a következő évek oktatáspolitikai változásait is. Deklarálja az 
iskolák szakmai önállóságát és a pedagógusok szakmai függetlenségét, valamint a tanulók, szülők, pedagógusok jogait. Az alapelvekben pedig kinyilvánítja a társadalmi esélyegyenlőség megvalósulásának elősegítését $[9 . \S 1$.) 2.) 3.)]. A törvény megjelenését követően, minisztériumi engedéllyel, kísérleti jelleggel egyre több óvoda és általános iskola vállalta sérült gyermekek/tanulók integrált nevelését. Hosszú távon azok váltak eredményesekké, amelyekben a többségi pedagógusok felkészültek az integrációs nevelésre. A felkészítést kezdetben a Bárczi Gusztáv Gyógypedagógiai Tanárképző Főiskola érintett tanszékeinek oktatói tartották.

A közoktatásban elindult változások, az átalakuló társadalmi igények a tanítóképzéssel szemben is új elvárásokat fogalmaztak meg. A tartalmilag megújított négyéves tanítóképzés bevezetését megelöző, az 1986 és 1988 közötti helyzetfeltáró előtanulmányokat összefoglaló kiadványban Hunyady Györgyné kiemeli: a tanítóképzés megújításakor tekintetbe kell venni, hogy „.. a a tanítás tartalmának megválasztásában nő a pedagógus szerepe, s amelyben a pedagógus olyan differenciált metodikával dolgozik, ami lehetővé teszi a különböző ritmusban, tempóban fejlődő gyermekek egyaránt sikeres előrehaladását" (Hunyadyné, 1990, 6.).

A hazai tanítóképzésben a Budapesti Tanítóképző Főiskolán elsőként vezették be a differenciált fejlesztés elméletét, módszereit, gyakorlati alkalmazását megismertető stúdiumot (Hunyadyné, 2003). Ez a fejlesztési koncepció már magában rejti az integrációs nevelésre felkészítés gondolatát is, de a képzés tartalmi részeként csak az olvasás-, írászavar és az enyhe beszédhibák korrekcióját megalapozó „logopédiai alapismereteket” javasolja. Komoly elörelépés, hogy szükségesnek tartja a differenciált tanulásszervezés beépítését a tantárgy-pedagógiákba, valamint a gyakorlatvezetők és a hallgatók tanítási gyakorlataiba is. A tartalmilag megújított négyéves tanítóképzés kísérleti bevezetését 1989-ben - az országban egyedüliként - a Budapesti Tanítóképző Főiskolán 250 fös évfolyammal kezdték meg.

Ugyanebben az időszakban a fogyatékos gyermekek érdekeit is érintő nemzetközi dokumentumok születtek. 1989. november 20-án New Yorkban kihirdették a gyermekek jogairól szóló egyezményt, amit 1991 májusában Magyarországon is törvényerőre emeltek. Az ENSZ Közgyülése 1993-ban fogadta el a fogyatékos személyek esélyegyenlőségére vonatkozó alapszabályt. Ez kimondja, hogy az államok biztosítsák az ép társakkal együtt, integrált formában történő alap-, közép- és felsőfokú oktatási lehetőségeket a fogyatékos gyermekek, fiatalok és felnőttek részére. Kitér azonban arra is, hogy az iskolarendszer még nem tudja minden fogyatékos gyermek egyéni szükségleteit kielégíteni, így szükség van a szegregált intézményi formákra is. De kiemelt feladatként jelöli meg a tanulók olyan szintü felkészítését, hogy tanulmányaikat többségi intézményekben folytathassák. Egy évvel később, 1994-ben a spanyolországi Salamancában a speciális szükségletek pedagógiájával foglalkozó, az UNESCO által szervezett világkonferencián vetették fel az integrált nevelés továbbfejlesztését, az inkluzív iskolai oktatást. A világ valamennyi kormányát 
felszólították arra, „hogy törvényeikbe foglalják bele az inkluzív oktatás elvét, felvéve valamennyi gyermeket a többségi iskolába, kivéve, ha kényszerítő okok késztetnek az ettől eltérö lépésekre" (Csányi, Zsoldos, 1994, 48). Az 1993. évi LXXIX. sz. közoktatási törvény ezt szabályozta is Magyarországon, de a pedagógusok még a fogadásra sem voltak felkészülve, az inkluzivitás gondolata szinte megvalósíthatatlannak tünt számukra.

A felsőoktatásban oktatók is tanulmányutakon ismerkedtek a modellértékü gyakorlatokkal, a szöveges értékelés megvalósításával, tapasztalataival, a differenciáló neveléssel kapcsolatos továbbképzésekkel. A gyógypedagógus- és a többségi pedagógusképzés oktatói közös tréningeken, kutatásokban vettek részt. Az előadó maga is résztvevője volt annak az UNESCO égisze alatt rendezett, „Hatékony iskolát mindenkinek - speciális szükségletek az osztályban” címü képzők tanfolyamának, ahol néhány vidéki és a budai tanítóképző oktatóival együtt saját élményű tanulásban sajátíthatták el a kooperatív tanulási technikákat, a differenciált feladatvégzést, szervezést, az eltérő képességű gyermekek szükségleteihez is alkalmazkodó tervezést, óravezetést. Az itt elsajátított speciális ismereteket rövid időn belül beépítették a tanítóképzésbe is, amit a Hunyady Györgyné témavezető által irányított $\mathrm{K}+\mathrm{F}$ kutatási programok beszámolói és a pályázatok eredményeként összeállított szöveggyüjtemények, tantárgyleírások is igazolnak.

\section{Befogadást lehetővé tevő inkluzív pedagógiai szemlélet, gyakorlat a tanítóképzésben}

A korszerü, a nemzetközi gyakorlathoz is egyre jobban közelítő szemlélet, a fogyatékos tanulók integrációjának elméleti és gyakorlati ismeretei már beépültek az 1989-ben indított négyéves kísérleti tanítóképzésbe is, de markánsabbá a 157/1994. (XI.17.) sz. kormányrendelet szerint indított, az 1-6. osztályt egységes pedagógiai szakaszként kezelő tanítóképzésben vált.

A szak indítását megelőzően ,a budai képző - hasonlóan más főiskolákhoz - kialakította saját helyi tantervét, a tanszékek kidolgozták programjaikat" (Bollókné, 1999, 2). E programok erénye, hogy a különböző tantárgypedagógiákba is beépítették a tantárgyi differenciálás ismereteit. A pedagógiai és pszichológiai tárgyak közt új elem az alkalmazott pedagógiától elkülönülö differenciáló pedagógia, valamint a differenciálás pszichológiája. A differenciáló pedagógia tárgy tartalmában már szerepelt a befogadó, integráló nevelés-oktatás. 1996-tól a hallgatók felkészülését a Neveléstudományi Tanszék két oktatója, Gereben Ferencné és Kereszty Zsuzsa által szerkesztett „Különböznek (Differenciálás kisiskolás korban)” címü tanulmánykötet is segítette/segíti. 1990től a Neveléstudományi Tanszék Hunyady Györgyné témavezetésével és részvételével több, a differenciálást, integrációt, inkluzív nevelést érintő kutatásban és pályázati munkában vett részt. Ezek eredményei: jegyzetek, könyvek, útmutatók, tájékoztató és feladatgyüjtemény, tantárgyi differenciálást segítő feladatgyüjtemények, oktatófilmek, továbbképzési programok, továbbképzések, új, a gyógypedagógiai oktatást, fejlesztést, szakértői 
tevékenységet bemutató gyakorlati színterek bevonása a képzésbe stb. „Több éves fejlesztő munka eredményeként kikristályosodott két, egymásra épülő tantárgy tananyaga (A differenciálás pszichológiai alapjai; A differenciálás pedagógiája), a hozzájuk csatlakozó gyakorlatok rendszere, illetve megtörtént két, a differenciált fejlesztésre specializálódott szakirányú továbbképzési szak alapítása is" (Hunyadyné, 2003, 8).

Az ENSZ, az UNESCO és más nemzetközi szakmai szervezetek felhívásai, valamint az érvényes hazai törvényi szabályozás az inkluzív nevelést mint jogot rögzíti. Ez a tanítóktól is más szemléletet, a speciális szükségletü gyermekek elfogadását, a hozzájuk igazodó differenciált fejlesztési és oktatási gyakorlatot, a gyógypedagógussal és a szülökkel való szorosabb együttmüködést és gazdag módszertani ismeretet követel. Ennek szellemében az ELTE Tanító- és Óvóképző Karán 2006 óta a mindenki számára kötelező Differenciáló pedagógia és a Differenciálás pszichológiája mellett, a kötelezően választható tárgyak keretében kínálja a hallgatóinknak a Gyógypedagógiai alapismeretek, az Integráló pedagógia, az Inkluzív nevelés tárgyak felvételét. 1997-ben indult, és azóta is keresett posztgraduális képzési program a Tanító, fejlesztési (differenciáló) szakirányú továbbképzés. Ennek keretében a már gyakorló pedagógusok elsajátíthatják a gyermekek fejlettségi szintjéhez, cselekvési kompetenciájához igazodó és a tanulók együttmüködésére is alapozó inkluzív pedagógiai szemléletet, a gyakorlatot megalapozó ismereteket és a differenciált fejlesztési eljárásokat. A változás azonban még hosszú időt vesz igénybe. Ezt bizonyítják a kb. másfél évtizede folyamatosan végzett kutatások is, amelyeket alsó tagozatos pedagógusok körében végeznek. „... A differenciálásnak a hazai gyakorlatban olyan változatos értelmezése él, amely szerint az a gyenge tanulók felzárkóztatására és/vagy a tehetséges tanulók fejlesztésére irányul; szórványos a valamennyi tanuló fejlesztésére kiterjedő értelmezés" (M. Nádasi, 2003, 13).

Az inkluzív oktatás nemcsak a közoktatásban tanító pedagógusoktól, hanem a felsőoktatás tanáraitól is szemléletváltást igényelt. Ebben úttörő szerepet töltött be Hunyady Györgyné, amit szakmai munkássága is bizonyít. A gyógypedagógiai szemlélet beépítését szolgálta $\mathrm{s}$ mind a mai napig szolgálja több kutatás és pályázati munka vezetése és/vagy azokban való részvétele, publikációi, oktatói, PhD-témavezetői munkássága. Ezek közül néhány: Az új rendszerü négyéves tanítóképzés, a Step by step; A pedagógiai és pszichológiai tárgyak új rendszere; A differenciálásra felkészítő tanítóképzés programjának kifejlesztése; A 3-12 éves gyermekekkel foglalkozó fejlesztő pedagógusok képzése; A gyermekek egyéni különbségeit figyelembevevő tantárgy-pedagógiák és a differenciálásra felkészítő tanítóképzés programjának kifejlesztése, valamint a „Differenciált fejlesztés és kooperatív formák: új szemlélet és tartalom a szakmódszertanokban” program.

Még ma is fel-fellángol a vita: integráció vagy szegregáció, de azt senki sem vitatja, hogy a többségi pedagógia szemléletét, módszertani gazdagodását a gyógypedagógia is erősen befolyásolta és viszont. Hunyady Zsuzsa munkásságával példát mutat arra, hogy milyen fontos az új pedagógiai és 
határterületi nézetek megismerése, az azokra való időben történő reagálás, a nem szolgai módon történő átvétel, hanem azok tudományosan megalapozott, kritikus módon történö beépítése szemléletmódunkba, gyakorlatunkba. Az ö befogadó szemlélete tette lehetővé, hogy gyógypedagógusként előadásommal én is köszöntőt mondhassak.

\section{Jegyzetek}

Bálint, M. (1987): Hiperaktivitás és iskolai teljesitménykudarcok. Oktatáskutató Intézet, Budapest.

Bollókné dr. Panyik Ilona (1998): „Az 1-6. osztályt egységes pedagógiai szakaszként kezelö tanitóképzés program” címü 034 kódszámú KOMA-pályázat teljesitése. ELTE TÓK, Irattár.

Csányi Yvonne (szerk. 1995): Együttnevelés - Speciális igényü tanulók az iskolában. Iskolafejlesztési Alapítvány, OKI Iskolafejlesztési Központ, Budapest.

Csányi Yvonne, Zsoldos Márta (1994): Világkonferencia a speciális szükségletủek neveléséröl. In: Új Pedagógiai Szemle, 44. évf. 12. sz. 41-50.

Gordosné Szabó Anna (2010): 110 éves a gyógypedagógus-képzés Magyarországon. In: Gyógypedagógiai Szemle, XXXVIII. évf. 4. szám, 317-332.

Gordosné Szabó Anna (2000a): A magyar gyógypedagógus-képzés története. Eötvös Loránd Tudományegyetem Bárczi Gusztáv Gyógypedagógiai Főiskolai Kar, Budapest.

Gordosné Szabó Anna (2000b): A gyógypedagógiai iskoláztatás és a gyógypedagógiai szakemberképzés elmúlt száz évéröl. In: dr. Salné Lengyel Mária (szerk.): $A$ gyógypedagógiai oktatás helyzete az ezredforduló Magyarországán. OKI PTK, Budapest.

Hunyady Györgyné és mtsai (1987): A tanitóképzés tantervi irányelvei. Müvelődési Minisztérium, Budapest.

Hunyady Györgyné, Bollókné Panyik Ilona (1989): Kisérleti négyéves tanitóképzés irányelvei. Budapesti Tanítóképző Föiskola, Budapest.

Hunyady Györgyné, Magyarfalvi Lajos (1990): A négyéves tanítóképzés elözményeinek és koncepcióinak vázlata. In: Magyarfalvy Lajos (szerk.): A tartalmilag megújitott négyéves tanitóképzés (helyzetfeltáró elötanulmányok). OPKM, Budapest.

Hunyady Györgyné (2000): A négyéves „tanító” szak programja: bevezetés és kommentár. In: Kovátsné dr. Németh Mária (szerk.): Óvó- és tanitóképzés az ezredfordulón. Kaposvári Egyetem Csokonai Vitéz Mihály Pedagógiai Föiskolai Kar, Kaposvár. 89-101.

Hunyady Györgyné (2003): Bevezető egy rendhagyó (tantárgy) pedagógiai jegyzethez. In: Hunyady Györgyné (szerk.): Differenciált fejlesztés - kooperatív tanulás. ELTE TÓFK, Budapest. 7-11.

Hunyady Györgyné, Bollókné Panyik Ilona (2003): A tanítóképzés az integrált felsőoktatásban. In: Új Pedagógiai Szemle, LIII. évf. július-augusztus, 4-17.

Hunyady Györgyné (2012): Rendszerváltás a tanítóképzésben. Kísérleti négyéves képzés a budai tanítóképzőben (1986-1994). In: Iskolakultúra, XXII. évf. 1. szám, 36-49.

M. Nádasi Mária (2003): A differenciált fejlesztés alapjai. In: Hunyady Györgyné (szerk.): Differenciált fejlesztés - kooperativ tanulás. ELTE TÓFK, Budapest. 11-31.

M. Nádasi Mária (2007): Adaptivitás az oktatásban. ELTE Eötvös Kiadó Kft. Budapest. 
Réthy Endréné (2002): A speciális szükségletủ gyermekek nevelése, oktatása Európában. Az integráció és inklúzió elméleti és gyakorlati kérdései. In: Magyar Pedagógia, 102. évf. 3. szám, 281-300.

Torgyik Judit (2004): Multikulturális társadalom, multikulturális nevelés. In: $U_{j}$ Pedagógiai Szemle, LIV. évf. 4. szám, 4-15.

A tanítóképző főiskolai tanterv megvalósításának tapasztalatai és a tantervi korrekcióra irányuló javaslatok. Belső használatra készült a Budapesti Tanítóképző Főiskola házi sokszorosító üzemében. (szerkesztő és kiadás éve nincs feltüntetve).

A Neveléstudományi Tanszék irattárában fellelhető tantervfejlesztési és pályázati dokumentumok.

A VKM 5300/1949 sz. rendelete.

Az 1961. évi III. törvény a Magyar Népköztársaság oktatási rendszerérö1.

Az 1985. évi I. törvény az oktatásról.

A tanítóképzés tantervi irányelvei, 1987.

1991. évi LXIV. törvény a Gyermek jogairól szóló, New Yorkban, 1989. november 20-án kelt Egyezmény kihirdetéséről.

Az 1993. évi törvény a fogyatékos személyek esélyegyenlőségéröl.

Az 1993. évi LXXIX. törvény a közoktatásról.

Az 157/1994. (XI.17.) sz. kormányrendelet. 